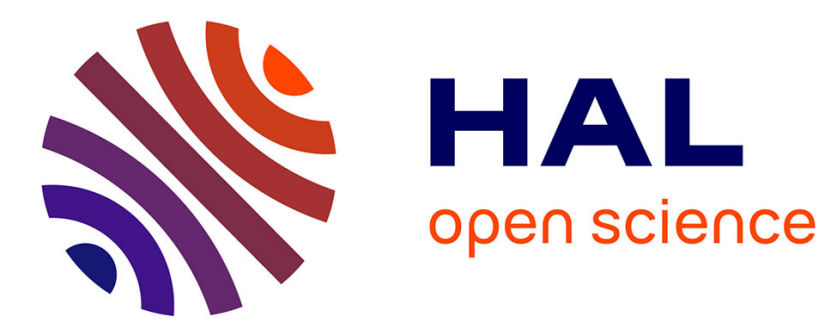

\title{
Advances in Analyzing Virus-Induced Alterations of Host Cell Splicing
}

Usama Ashraf, Clara Benoit-Pilven, Vincent Lacroix, Vincent Navratil, Nadia Naffakh

\section{- To cite this version:}

Usama Ashraf, Clara Benoit-Pilven, Vincent Lacroix, Vincent Navratil, Nadia Naffakh. Advances in Analyzing Virus-Induced Alterations of Host Cell Splicing. Trends in Microbiology, 2019, 27 (3), pp.268-281. 10.1016/j.tim.2018.11.004 . hal-01964983

\section{HAL Id: hal-01964983 \\ https://hal.inria.fr/hal-01964983}

Submitted on 21 Oct 2021

HAL is a multi-disciplinary open access archive for the deposit and dissemination of scientific research documents, whether they are published or not. The documents may come from teaching and research institutions in France or abroad, or from public or private research centers.
L'archive ouverte pluridisciplinaire HAL, est destinée au dépôt et à la diffusion de documents scientifiques de niveau recherche, publiés ou non, émanant des établissements d'enseignement et de recherche français ou étrangers, des laboratoires publics ou privés.

\section{다(1) $\$$}

Distributed under a Creative Commons Attribution - NonCommercial| 4.0 International 
1

2

3

4

5

6

7 Naffakh $^{1,2,3 *}$

8

9

10

11

12

13

14

15

16

17

18

19

20

21

22

23

24

25

26

27

28

29

30

31

32

33 34

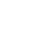
France.

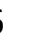
7 28

\section{Keywords}

3 Systems biology

\section{Advances in analyzing viral-induced alterations of host-cell splicing}

Usama Ashraf ${ }^{1,2,3}$, Clara Benoit-Pilven ${ }^{4,5}$, Vincent Lacroix ${ }^{5}$, Vincent Navratil ${ }^{6,7}$, Nadia

${ }^{1}$ Institut Pasteur, Unité de Génétique Moléculaire des Virus à ARN, Département de

Virologie, F-75015 Paris, France

${ }^{2}$ CNRS, UMR3569, F-75015 Paris, France

${ }^{3}$ Université Paris Diderot, Sorbonne Paris Cité, EA302, F-75015 Paris, France

${ }^{4}$ INSERM, U1028; CNRS, UMR5292; Lyon Neuroscience Research Center, Genetic of Neurodevelopment anomalies Team, F-69000 Lyon, France

${ }^{5}$ Université de Lyon, F-69000, Lyon; Université Lyon 1; CNRS, UMR5558, Laboratoire de Biométrie et Biologie Evolutive, F-69622 Villeurbanne, EPI ERABLE - INRIA Grenoble, RhôneAlpes, France

${ }^{6}$ PRABI, Rhône Alpes Bioinformatics Center, UCBL, Lyon 1, Université de Lyon, F-69000 Lyon,

${ }^{7}$ European Virus Bioinformatics Center, Leutragraben 1, D-07743 Jena, Germany.

* correspondence : nadia.naffakh@pasteur.fr (N. Naffakh)

Alternative splicing

1 Virus-host interaction

2 Genome-wide transcriptomics 


\section{Abstract}

36 Alteration of host cell splicing is a common feature of many viral infections which is 37 underappreciated because of the complexity and technical difficulty of studying alternative 38 splicing regulation. Recent advances in RNA sequencing technologies revealed that up to 39 several hundreds of host genes can show altered mRNA splicing upon viral infection. The 40 observed changes in alternative splicing events can either be a direct consequence of viral 41 manipulation of the host splicing machinery or result indirectly from the viral-induced innate 42 immune response or cellular damages. Analysis at a higher resolution with single-cell 43 RNAseq and a higher scale with the integration of multiple omics datasets in a systems 44 biology perspective will be needed to further comprehend this complex facet of virus-host 45 interactions.

46

47 


\section{Alteration of cellular splicing: a complex facet of virus-host interactions}

In higher eukaryotic cells most genes are transcribed as precursor messenger RNAs (premRNAs) that undergo splicing, a maturation process through which RNA sequences (introns) are removed and the remaining sequences (exons) are ligated together. Splicing occurs in the nucleus and is catalyzed by the spliceosome, a large and highly dynamic ribonucleoprotein complex $[1,2]$. Most mammalian pre-mRNAs are subject to alternative splicing (AS), and human genes contain on average 8.8 exons and 7.8 introns per gene, giving rise to an average of 3.4 alternatively spliced isoforms $[3,4]$. The most common types of AS events are the use of alternative donor and acceptor splice sites, exon skipping, alternative use of mutually exclusive exons, and intron retention. Alternative splicing expands the diversity of proteins that can be expressed from a given gene, and can also modify cisregulatory elements that govern the stability and translation of mRNAs. In recent years, head-to-tail back-splicing events that result in the formation of non-coding circular RNAs (circRNAs) have also been observed to play key regulatory roles in a variety of biological processes, including antiviral immunity $[5,6]$. Splicing is tightly coupled to transcription, and is controlled by cis- and trans-acting elements as well as through chromatin structure and signalling pathways $[3,5,7]$. The advent of high-throughput RNA sequencing technologies (RNAseq) has opened up a new era in studying how AS is regulated and shapes the cellular proteome in response to changes in environmental conditions (e.g. [8]).

Viruses modulate host gene expression in order to favor viral replication and evade antiviral responses. They have evolved mechanisms to affect cellular transcription, mRNA processing and nuclear export, mRNA decay, and translation [9-11]. RNAseq, proteomic and interactomic studies are now beginning to provide a global view of viral-induced alterations of cellular splicing and insights into how they may impact viral pathogenesis. Herein, we review the recent developments in the field, we discuss how current limitations could be overcome in the future, and what advances may be expected from the integration of splicing isoforms datasets into a systems biology perspective.

\section{Viral manipulation of the host splicing machinery}

Viruses that replicate in the nucleus of infected cells and gain access to the splicing machinery (e.g. adenoviruses, herpesviruses, and influenza viruses) have evolved an 
expansion of their coding capacity by producing spliced viral mRNAs. However, manipulation of the host splicing machinery is not exclusive to nuclear viruses and has also been observed with viruses that replicate in the cytoplasm such as picornaviruses or flaviviruses (Table 1). This can be accounted for by the nucleo-cytoplasmic shuttling of some viral proteins (e.g. the dengue virus NS5 protein [12]) and splicing factors (e.g. SR proteins [13]), increased nuclear permeability upon viral infection [14] or signaling pathways triggered by viral infection [15]. Components of the splicing machinery commonly targeted across different virus families are the small nuclear ribonucleoproteins (snRNPs), serine/arginine-rich (SR) proteins, and heterogeneous nuclear ribonucleoproteins (hnRNPs). The U1 to U6 snRNPs are core components of the spliceosome, whereas SR and hnRNP proteins are involved in the regulation of constitutive and alternative splicing. Different viruses appear to induce similar types of alterations, i.e. changes in the level of expression, protein-protein or protein-RNA interaction pattern, localization, phosphorylation and/or intrinsic activity of splicing factors (Table 1).

Among the genes that appear differentially expressed upon viral infections in transcriptomic and proteomic datasets, the overall enrichment of splicing-related genes is generally not reported. However, particular splicing factors can undergo significant changes in expression upon viral infection. As an example, expression of EFTUD2, a U5-snRNP associated factor, was found to be decreased upon HCV infection of cultured cells and in liver samples from HCV-infected patients; downregulation of EFTUD2 impairs the splicing of RIG-I and MDA5 pre-mRNAs and therefore enables the virus to circumvent the innate antiviral response [16]. Phosphoproteomic profiling provides an additional layer of information by revealing viralinduced changes in the phosphorylation status of host proteins. Dynamic phosphorylation/dephosphorylation is known to regulate the function of splicing factors, most notably SR proteins [17]. HIV-1 entry triggers early changes in the phosphorylation of five SR proteins, including SRRM2 which regulates the splicing of HIV-1 transcripts [18]. Later in infection there is evidence that the HIV-1 protein Vpr modulates the activity of SR proteinspecific kinases and the phosphorylation of SRRM2 [19]. In the pre-omics era, the herpesvirus ICP27, adenovirus E4-ORF4 and papillomavirus E1^E4 proteins have also been reported to regulate SR proteins phosphorylation in order to facilitate their replication [20- 
22] (Table 1). Altogether these findings point to changes in $S R$ phosphorylation as a mechanism commonly triggered by multiple viruses to co-opt the splicing machinery. Interrogation of the VirHostNet 2.0 public database dedicated to virus-host protein-protein interactions (PPIs) [23] reveals that a large proportion of known splicing factors have at least one reported interaction with a viral protein, pointing to the spliceosome as a frequent viral target (Figure $1 \mathrm{~A}$ and $1 \mathrm{~B}$ ). Most of the data derive from a yeast two-hybrid or affinitypurification mass spectrometry screen with no systematic experimental validation of the interactions and therefore cannot be assumed a priori as high confidence data [14]. However data integration helps reveal splicing factors which are found to be associated with multiple viral species and represent potentially relevant targets for onward studies, e.g. DDX5 and FUS (Figure 1C). Some PPIs have been identified in low throughput studies and are well documented such as the recently identified interaction between the reovirus protein $\mu 2$ and the SR protein SRSF2, which alters SRSF2 function and determines the virus ability to counteract the interferon response [24]. Additional PPIs and associated effects on the host splicing machinery are listed in Table 1. Furthermore, viral RNAs can act on the splicing machinery, as exemplified by the changes in AS events observed upon sequestration of the HuR protein by the 3'UTR of Sindbis virus [25], (Table 1).

\section{Peering into viral-induced alterations of host alternative splicing events}

To date there are only a few studies that performed transcriptome-wide micro-array or RNAseq analysis of cellular AS events in virus-infected cells (Table 2). They concern herpesviruses [26-28], reoviruses [24, 29], dengue viruses (DENV) [12, 30], Zika virus [31] and influenza viruses [32], and reveal several hundreds of host genes that show altered mRNA splicing upon infection. When examined, no correlation was found between changes in AS events and changes in mRNA expression levels. Validation by RT-PCR or RT-qPCR of a selected subset of the predicted differential AS events is compulsory and usually performed to sort out and confirm RNAseq findings. Validation rates can only be determined if a large enough number of AS events is assayed, and are likely to depend on the metrics and statistical analysis that are used. In the few studies which provide GO terms enrichment analysis on the list of differentially spliced genes in virus-infected cells, an enrichment in genes related to cell cycle, gene expression and/or RNA metabolism was reported [24, 27, 
30-32]. Consistently with previous reports that the AS landscape varies between human tissues [33], neural progenitor cells infected with the human cytomegalovirus (HCMV) exhibited fewer AS changes compared to fibroblasts and only half of altered exon-skipping overlapped in both cell types [26]. Exon-skipping, which is most frequently detected in the human transcriptome [33] accounts for the largest share of infection-altered AS events in all except the DENV5 study [12]. Interestingly intron retention (IR) which, although identified early on in spliced viral mRNAs, was until recently considered a rare event in mammalian cells, was found to represent a substantial proportion ( $>20 \%$ ) of infection-altered AS events in herpes simplex virus-1 (HSV-1) and DENV5-infected cells $[12,27]$. These observations align with recent findings that IR is actually a common AS event in mammalian cells, although the fate of intron-retaining mRNAs regarding nucleo-cytoplasmic export or nonsense mediated decay is not fully understood [34]. Taken together with a recent report that influenza virus NS1 protein primarily binds intronic sequences [35], they suggest that some viruses may have evolved specific mechanisms to alter host cell expression through increased IR. Finally, within the last couple of years the first reports of viral-induced alterations of cirRNAs were published. Notably, cirRNAs were found to be expressed and associated with the NF90/NF110 factor at lower levels upon Vesicular Stomatitis Virus (VSV) infection, which results in increased NF90/NF110 binding to viral mRNAs in the cytoplasm and thereby likely contributes to the antiviral immune response [36]. A global dysregulation of circRNAs was observed upon infection with HSV-1, which could potentially modulate the cellular transcriptional responses through the miRNA sponge function of circRNAs [37].

Splicing alterations observed upon infection potentially result from the combination of two types of mechanisms: i) they can be caused by a viral manipulation of the splicing machinery, as described above; or ii) they can be related to viral-induced cellular damages or innate immune responses (Figure 2). Indeed, there is increasing evidence that AS is a mechanism to regulate the immune responses to pathogens [38-40] (Box 1), as well as apoptosis [41], DNA damage response [42] and endoplasmic reticulum stress response [43]. Integration of multiomics data will probably be key to distinguishing between direct and indirect effects of viral infection on the cellular splicing machinery and uncovering of the complex mechanisms by which the host-cell splicing landscape is modified (see below). 
170 In some instances, differences in viral-induced splicing changes were reported when viral 171 variants were compared. Reovirus strain T1L, compared to strain T3D which differs in that its $172 \mu 2$ protein does not localize to nuclear speckles, triggered more splicing changes i.e. 369 173 compared to 142 , with an overlap of only 35 changes. The cellular processes which were 174 most affected by T1L infection, i.e. gene expression and RNA post-transcriptional 175 modification, were not strongly affected by T3D infection [24]. Comparison of a subset of AS 176 events upon infection with DENV2 and DENV4 revealed differences, suggesting a possible 177 serotype specificity in AS alteration [12]. However the molecular mechanisms that lead to 178 specific alterations of the splicing landscape remain largely unknown. The only evidence for 179 a sequence recognition mechanism comes from Tang et al. who showed that the ICP27 180 protein of HSV-1 mediates splicing alterations in genes that are GC-rich, with suboptimal 181 splicing sites and cytosine-rich sequences close to the $5^{\prime}$ splice site [44]. The presence of a 182 conserved 41 nucleotide motif was observed in 93 out of 240 AS events that were dysregulated upon infection with the reovirus strain T3D [29], however this motif does not correspond to a predicted RNA regulatory motif and the significance of this observation 185 remains to be demonstrated.

186 Importantly, transcriptomics studies revealed that not only splicing but also other features of 187 cellular mRNAs can be altered upon viral infection. For instance, DENV1 was found to induce alterations in the relative usage of transcriptional start sites, in addition to splicing changes [30]. Infection with herpesviruses was shown to trigger widespread disruption of transcription termination of cellular mRNAs [26-28], which in the case of HCMV infection was attributed to a strong induction of the host RNA-binding protein CPEB1 [26].

192 Transcription extends over thousands of nucleotides beyond poly(A) sites and into 193 downstream genes, it interferes with the analysis of transcriptional and splicing regulation of 194 the downstream gene and can generate novel intergenic splicing between exons of two neighbouring genes [28]. Defective transcription termination of cellular mRNAs was also very 196 recently reported in influenza virus-infected cells [45-47]. While most studies provide 197 information about the steady-state levels of mRNA isoforms, a few of them rely on the NET198 Seq method [45] or on 4sU tagging of mRNAs [28] to provide a real-time view of viral199 induced changes in co-transcriptional RNA processing. As these methods allow to detect 200 actively or newly transcribed mRNAs, they can also help avoid biaises due to isoform-specific 
201

202

203

204

205

206

207

208

209

210

211

212

213

214

215

216

217

218

219

220

221

222

223

224

225

226

227

228

229

230

231

differences in the stability of mRNA. Transcriptomic analysis and mechanistic understanding of how viral infection impacts cellular mRNA co- and post-transcriptional processing is an expanding field, constantly evolving in response to progress in cellular biology (e.g. the recent findings on the biogenesis and function of circRNAs) and in technologies (as discussed below).

\section{Towards a more accurate view: methodological challenges}

RNAseq transcriptomic analysis of AS is a challenging issue, and even more so when performed on a virus-host system. Accurate quantification of isoform abundance requires a high read number (about 50 millions paired-end reads of at least $75 \mathrm{bp}$ are recommended for the human transcriptome), which to date can only be provided by the Illumina technology. However a serious limitation of Illumina RNAseq is that it relies on short reads, so that the resolution of exon connectivity and full-length isoform structure cannot be achieved (Box 2). Upon viral infection the reads mapping to viral mRNAs may represent 5$75 \%$ of the total number of reads (Table 2 ), therefore the sequencing depth of virus- and mock-infected samples must be adjusted accordingly. The degree of variability of AS viralinduced perturbations also need to be taken into account when setting the sequencing depth and the number of biological replicates, in order to differentiate biologically relevant changes from transcriptional noise.

Many viruses induce host-cell transcription shut-off [10] although specific genes (e.g. IFNstimulated genes, cytokines) can escape this shut-off and be up-regulated. Marked differences between the gene expression profiles of mock- and virus-infected cells poses a challenge for accurate comparison of isoform abundance. Commonly used RNAseq normalization methods [48] make the assumption that a core set of genes is not differentially expressed and mainly correct for sequencing depth. Normalization methods taking into account other variability factors (e.g. the average amount of cellular RNA per cell) besides sequencing depth for host-pathogen dual RNAseq experiments need to be developed [49].

Another methodological challenge of viral-host RNAseq lies in the ability to deal with cell-tocell heterogeneity during infection. Usually high multiplicities of infection are used and it is verified or assumed that almost all cells are infected. However, single-cell RNAseq 
232 (scRNAseq) experiments revealed extensive variability from one individual cell to another in

233 terms of production of intracellular viral RNAs and cellular responses [50-52]. RNAseq

234 experiments on polyadenylated mRNAs or circRNAs extracted from bulk cell cultures or

235 tissues are providing an average measure of isoform abundance; they are potentially

236 masking heterogeneity that occurs in the dynamics of infection and/or specific

237 transcriptomic profiles in a subset of cells which could be relevant to the viral phenotype.

238 Single cell RNAseq can be used for transcriptome-wide differential splicing isoform

239 quantification, however this requires specific bioinformatics tools and normalization

240 procedures to be developed, to cope with the low reads counts, the heterogeneity and noise

241 in the datasets [53-55].

242 So far, most RNAseq analyses of splicing events in virus-infected cells have been conducted

243 with cancer cell lines and/or viral laboratory strains. Such experimental conditions have

244 practical advantages (ready availability, ability to infect almost $100 \%$ of the cells, and higher

245 reproducibility), however they may not accurately reflect physiological infection. The

246 development of scRNAseq, which allows discrimination between infected and uninfected

247 cells, will probably encourage the use of field viral isolates and more relevant cellular

248 systems such as primary cells or tissue explants. Novel perspectives will be opened by the

249 use of induced human pluripotent cells (iPS) which upon differentiation can serve as

250 convenient surrogates for primary cells that are difficult to isolate and culture [56], and 3D

251 organoid cultures which can provide an accurate model for the micro-anatomy of an organ 252 [57].

253

254 Integration of isoforms datasets in a systems biology perspective

255 The rapid advancement of high-throughput technologies has led to the development of the 256 systems biology field, which aims at modeling the properties of complex biological systems, 257 and predicting their response to biological or chemical perturbations. The commonly used 258 "top down" systems biology approach turns RNAseq measurement of expression levels into 259 a variable which can be included in a mathematical model, such as a generalized linear 260 model or a multivariate analysis (Principal Component Analysis, Singular Value 261 Decomposition, Partial Least Square). The variance across genes or isoforms, samples and 262 conditions is computed to identify statistically significant transcriptomics signatures, i.e. 
particular combinations of thousands of genes or isoform expression levels. The mechanistic interpretation of these signatures and the prioritization of candidate genes for downstream experimental validation remain challenging tasks. However, the use of transcriptomic signatures has already allowed genetically close viral strains to be robustly distinguished [58], species-specific responses to infection outlined [59] and the outcome of viral infections predicted [60]. It can also pave the way towards the discovery of relevant biomarkers [61]. Transcriptomic signature analysis has become a routine at the gene level, but little has been done so far at the isoform-level. Recent methodological developments - such as splicing signature comparison workflows for the discovery of candidate splicing regulatory elements

272 - have been applied to psoriasis studies $[62,63]$ and could be transferred to the analysis of 273 infected-cells in the future. Further progress in the field will also be enhanced by the 274 accessibility and the integration of published RNAseq datasets within open access 275 knowledge bases (e.g. ArrayExpress, Gene Expression Omnibus), which allows meta-analyses 276 to be conducted.

277 The integration of RNAseq datasets with other omics datasets, so far mostly proteomics, 278 interactomics and metabolomics datasets, has become a new way to rationalize the 279 deconvolution of the transcriptomics signal, and has been applied to virus-infected cells [6466] or patients [67]. To facilitate this integration step, network-based methods such as correlation network (e.g. WGCNA) or probabilistic models (e.g. MERLIN) are currently being investigated (reviewed in [68]). The main objective is to infer the transcriptional gene regulatory network and to prioritize a set of candidate genes, transcriptional factors or functional modules that are involved in viral infection. A growing number of studies combine newly generated experimental data with published datasets available in open access databases to identify the most relevant molecular pathways. For example, by combining proteomics and RNA-seq experimental data along with available gene-regulatory and protein-protein interaction networks Sychev et al. successfully implemented a computational model based on the Prize-Collecting Steiner Forest algorithm, which highlighted peroxisome lipid metabolism as an important function involved in KSHV (Kaposi's sarcoma associated herpesvirus) latent infection [65].

292 One should stress that integration is for now only performed at the gene-level. Gene 293 annotation knowledge bases (GO, Interpro, and KEGG) are exploited to investigate 
294 enrichment of specific biological or molecular functions (GSEA). Although they are 295 continuously being improved, gene annotations are still far from being complete [69], and 296 even more so at the isoform level and for non-model organisms. Gene annotations often 297 relate to a "reference isoform" which is assumed to be the predominant one, whereas the relative proportion of splicing isoforms may differ from one tissue to another. Alternative splicing may lead to the gain or loss of functional domains, catalytic sites and/or protein300 protein interfaces. However, the full set of alternative isoforms that effectively contribute to 301 proteomic diversity and represent "functional alloforms" remains to be characterized [70, 71]. Available Exon Ontology resources can be used to readily identify enriched functions of gene isoform subsets but they restrict the analysis at the exon-level [72]. The systematic characterization of AS isoforms function is a challenging task and might be accelerated 305 through bioinformatics prediction [72-74] or experimentally by using interactomics approaches $[75,76]$.

As molecular approaches to study virus-host interactions at a high level of mechanistic detail are also making steady progress, the "bottom up" systems biology approach also seem promising. In this approach the knowledge generated by the molecular and biochemical characterization of a subsystem and its response to perturbations is used to generate specific sub-networks, which can subsequently be integrated together with high-throughput data into larger molecular interaction networks [77-79]. In the case of the spliceosome machinery, subnetwork modeling is making progress through Bayesian probability modeling [80], food-web modeling [81], or deep-learning approaches [82], which offers advanced tools for studying its involvement and vulnerability upon viral infection. In return, research on the virus-spliceosome interplay will likely contribute to a better definition of the complex set of rules that can predict the splicing pattern of each isoform based on a comprehensive catalogue of cis-regulatory elements and their functional molecular interactions in various physiological and pathological conditions.

\section{Concluding remarks}

322 The importance of characterizing the transcriptome landscape of virus-infected cells at the 323 splicing level is highlighted by recent studies, which reveal significant AS alterations in 324 response to viral infections. The observed changes in AS events, which are regulated through 
325 a very complex protein-RNA interaction network, can either be a direct consequence of viral 326 manipulation of the host splicing machinery or result indirectly from viral-induced immune 327 responses or cellular damages. Integration of multiple omics datasets in a systems biology 328 perspective will be needed to comprehend this complex facet of virus-host interactions. 329 Beyond proteomics and interactomics, which have been most commonly combined with 330 RNAseq analysis so far, epigenomics and epitranscriptomics would also be relevant. Indeed, 331 viral infections may induce epigenetic $[83,84]$ or epitranscriptomic [85] modifications, and 332 both types of modifications may in turn affect splicing $[86,87]$. Genetic mutations that affect 333 AS, and consequently may determine phenotypic variability and individual susceptibility to 334 viral diseases, is also an interesting direction for future research [88]. Species-dependent AS 335 patterns of cellular genes could possibly be determinant for viral host-range, as suggested 336 recently for influenza viruses [89]. As technological advances in RNA sequencing and RNA 337 genomics will allow to study the interplay between cellular AS and viral infections at an 338 increasing scale and resolution, major challenges in terms of computational analysis and 339 storage of the corresponding datasets will need to be addressed, and the building of 340 pluridisciplinary research teams along the lines of the European Virus Bioinformatics Center 341 (http://evbc.uni-jena.de) [90] will be paramount. Integration of splicing isoform datasets 342 with other omics data may well contribute to the development of personalized prognosis 343 and management of infectious diseases and lead to therapeutic innovations. 


\section{Acknowledgements}

346 U.A. is part of the Pasteur - Paris University (PPU) International PhD Program, which has

347 received funding from the European Union's Horizon 2020 research and innovation 348 programme under the Marie Sklodowska-Curie grant agreement No 665807, and from the 349 Institut Carnot Pasteur Microbes \& Santé. C.B.P. has received funding from the Fondation 350 pour la Recherche Médicale. This study was supported by the ANR ASTER (Grant No ANR-16351 CE23-0001) and the LabEx IBEID (Grant No 10-LABX-0062).

352 
353 Box 1 : Role of alternative splicing in shaping immune responses.

354 In the recent years there has been growing evidence for a role of AS in shaping both innate 355 and adaptative immune responses [38-40]. Different isoforms have been found for key 356 players of the antiviral innate immunity, including pattern-recognition receptors (e.g. TLRs, 357 RIG-I, and MDA5), downstream signaling proteins (e.g. MyD88, MAVS, STING, TBK1, and 358 IRF3), and effectors (IFN Type I, IFNAR, cytokines and chemokines). The splicing factors 359 involved are known in a few cases : EFTUD2 regulates the splicing of RIG-I, MDA5 and 360 MyD88 [91], while SF3A1 affects the splicing of several genes of the TLR signaling pathway 361 including MyD88 [92]. In several instances, splice variants exert a negative feedback loop on 362 the signaling pathway, thereby probably controlling the intensity and duration of the 363 antiviral and inflammatory responses. Notably, RIG-I and STING splice variants whose 364 expression are up-regulated upon viral infection strongly inhibit RIG-I and STING signaling pathways, respectively [93, 94]. A viral-induced, alternatively spliced isoform of TPK-1 disrupts the interaction between RIG-I and MAVS and inhibits IFN-beta signaling [95]. Short isoforms of MAVS negatively regulate TLR3-mediated nucleic acid sensing [96], and limit selfaggregation of the full-length MAVS protein thereby preventing accidental antiviral innate immune signaling [97]. The contribution of AS to the regulation of humoral and cellular adaptative immune responses is also clearly recognized, however the mechanisms involved remain largely unknown. In B cells two mechanisms were recently uncovered : the HuR

372 protein, by regulating mRNA splicing upon B cell activation, is essential for antibody 373 response to a variety of antigens [98], while the ZFP318 factor regulates the AS-dependent 374 balance between IgM and IgD immunoglobulins [99]. In T cells, one of the best documented 375 examples is the AS of CD45 in response to antigen receptor-mediated signaling, which is 376 differentially regulated depending on the T cell lineage and the stage of activation (reviewed 377 in $[39,40])$.

378 
381 Box 2 : Resolving alternative splicing by short- or long-reads sequencing technologies.

382 Currently Illumina is the most commonly used RNAseq technology for transcriptome-wide 383 analysis of AS. However Third Generation Sequencing (TGS) technologies, such as the Pacific 384 Biosciences (PacBio) and Oxford Nanopore (ON) technologies, are emerging as alternative 385 platforms for AS analysis [100].

386 The major advantage of Illumina over the TGS technologies is its higher sequencing depth 387 (up to 400 million reads instead of 1 million for TGS), even more so in the case of dual 388 RNAseq when both the viral and host transcriptome need to be sequenced. High depth is 389 needed for the detection of minor isoforms and the robust quantification and statistical 390 analysis of AS events [101]. Another advantage of Illumina resides in its higher sequencing accuracy (about $0.1 \%$ error rates instead of $10-15 \%$ for TGS), which is particularly 392 advantageous when working on poorly annotated genomes of non-model organisms. 393 However, a major limitation of Illumina is that it generates short reads (75-300 bp) which 394 provides only local information about AS events and entails a challenging computational 395 reconstruction of full-length isoforms. The strength of TGS is their read length (1-100 kb), 396 which allows the direct characterisation of full-length transcripts with information not only 397 on alternative splicing and the coordination of distant exons [102] but also on alternative 398 transcription start and termination sites [103]. Moreover long reads allow to resolve 399 repetitive sequences, that are posing a major challenge for sequence assembly or alignment 400 from short-read datasets.

401 Future advances may lie in the Hybrid-Seq approach which combines short and long-read 402 technologies [101], the Synthetic Long-Read technology which exploits the assets of Illumina 403 with a short-read barcoding system to reconstruct full-length transcripts [104], or the very 404 swift evolution of long-read technologies. Particularly promising is the perspective of direct 405 RNA sequencing proposed by ON, which would avoid reverse-transcription- and 406 amplification-related biases in isoforms quantification [105]. 
Table 1. Viral targeting of the splicing machinery.

\begin{tabular}{|c|c|c|c|c|}
\hline Virus & Viral factor & Cellular Target & Associated cellular changes ${ }^{a}$ & References \\
\hline HSV-1 & ICP27 & $\begin{array}{l}\text { Binding to, relocalisation } \\
\text { and inhibition of SRPK1 }\end{array}$ & $\begin{array}{l}\text { Altered phosphorylation of SR } \\
\text { proteins }\end{array}$ & [22] \\
\hline HSV-1 & ICP27 & Binding to SF3B2* & ND & [106] \\
\hline HIV-1 & Vpr & Binding to SF32B* & Altered splicing of pre-mRNAs & [107] \\
\hline EBV & SM & Binding to SRSF3 & Altered splicing of STAT1 pre-mRNA & [108] \\
\hline HPV1 & E1^E4 & $\begin{array}{l}\text { Binding to and inhibition } \\
\text { of SRPK1 }\end{array}$ & $\begin{array}{l}\text { Altered phosphorylation of SR } \\
\text { proteins }\end{array}$ & [21] \\
\hline HPV16 & E2 & $\begin{array}{l}\text { Transactivation of } \\
\text { SRSF1-3 promoters }\end{array}$ & ND & [109] \\
\hline Adenovirus & E4-ORF4 & Binding to SRSF1, SRSF9 & Modulation of pre-mRNA splicing & [20] \\
\hline Influenza V & NS1 & Binding to U6snRNA & Inhibition of pre-mRNA splicing & [110] \\
\hline Influenza V & NS1 & Relocalisation of SRSF2 & ND & [111] \\
\hline Influenza V & NS1 & $\begin{array}{l}\text { Binding to and } \\
\text { relocalisation of NS1-BP }\end{array}$ & $\begin{array}{l}\text { Altered splicing of some pre-mRNAs } \\
\text { regulated by NS1-BP }\end{array}$ & {$[112,113]$} \\
\hline Poliovirus & $2 \mathrm{~A}$ & $\begin{array}{l}\text { Relocalisation of HuR, } \\
\text { TIA-1, TIAR }\end{array}$ & $\begin{array}{l}\text { Modulation of Fas } 6 \text { pre-mRNA } \\
\text { splicing }\end{array}$ & [114] \\
\hline Poliovirus & $2 \mathrm{~A}$ & Relocalisation of SRSF3 & ND & [115] \\
\hline EV-71 & 3D (Pol) & $\begin{array}{l}\text { Binding to and inhibition } \\
\text { of PRPF8** }\end{array}$ & $\begin{array}{l}\text { Blockage of pre-mRNA splicing and } \\
\text { mRNA synthesis }\end{array}$ & [116] \\
\hline FMDV & $3 C$ (Pro) & $\begin{array}{l}\text { Cleavage and } \\
\text { relocalisation of Sam68 }\end{array}$ & ND & [117] \\
\hline Reovirus & $\mu 2$ & $\begin{array}{l}\text { Binding to and } \\
\text { relocalisation of SRSF2 }\end{array}$ & Altered splicing of pre-mRNAs & [24] \\
\hline Rotavirus & NSP2, NSP5 & $\begin{array}{l}\text { Association with and } \\
\text { relocalisation of hnRNPs } \\
\text { and HuR }\end{array}$ & ND & [118] \\
\hline Sindbis V & nsP2 & Binding to hnRNPK & ND & [119] \\
\hline Alphaviruses & 3' UTR & $\begin{array}{l}\text { Binding to and } \\
\text { relocalisation of HuR }\end{array}$ & $\begin{array}{l}\text { Altered stability, splicing and poly- } \\
\text { adenylation of mRNAs }\end{array}$ & {$[25,120]$} \\
\hline HCV & 3'UTR & $\begin{array}{l}\text { Binding to and } \\
\text { relocalisation of HuR }\end{array}$ & ND & [121] \\
\hline DENV-1 & NS5 protein & $\begin{array}{l}\text { Binding to CD2BP2 } \\
\text { DDX23** }\end{array}$ & Altered pre-mRNA splicing in vitro & [12] \\
\hline VSV & $M$ & $\begin{array}{l}\text { Relocalisation of } \\
\text { hnRNPH }\end{array}$ & ND & [122] \\
\hline
\end{tabular}

$413{ }^{a}$ ND: not determined, * component of the U2 snRNP, ** component of the U5 snRNP, 
Table 2. Transcriptome-wide analyses of AS in virus-infected cells.

\begin{tabular}{|c|c|c|c|c|c|c|c|c|c|}
\hline & $\begin{array}{c}\text { Rutkowski } \\
\text { et al. } 2015 \\
\text { [28] }\end{array}$ & $\begin{array}{c}\text { Hu et al. } \\
2016 \\
{[27]}\end{array}$ & $\begin{array}{c}\text { Batra et al. } \\
2016 \\
{[26]}\end{array}$ & $\begin{array}{c}\text { Boudreault } \\
\text { et al. } 2016 \\
{[29]}\end{array}$ & $\begin{array}{l}\text { Rivera-S } \\
\text { et al. 2017 } \\
{[24]}\end{array}$ & $\begin{array}{l}\text { Sessions et } \\
\text { al. 2013 } \\
\text { [30] }\end{array}$ & $\begin{array}{l}\text { De Maio et } \\
\text { al. 2016 } \\
\text { [12] }\end{array}$ & $\begin{array}{c}\text { Hu et al. } \\
2017 \\
{[31]}\end{array}$ & $\begin{array}{c}\text { Fabozzi et } \\
\text { al. 2018 } \\
\text { [32] }\end{array}$ \\
\hline Virus & HSV-1 & HSV-1 & HCMV & Reovirus & Reovirus & Dengue V & Dengue V & Zika V & Influenza V \\
\hline $\begin{array}{l}\text { Host-cell } \\
\text { model }^{\mathrm{a}}\end{array}$ & $\begin{array}{l}\text { Human } \\
\text { Fibroblasts }\end{array}$ & $\begin{array}{l}\text { Human } \\
\text { Fibroblasts }\end{array}$ & $\begin{array}{l}\text { Human } \\
\text { Fibroblasts } \\
\text { \& NPC }\end{array}$ & $\begin{array}{l}\text { Murine } \\
\text { L929 cells }\end{array}$ & $\begin{array}{l}\text { Murine } \\
\text { L929 cells }\end{array}$ & $\begin{array}{l}\text { Human } \\
\text { HuH7 cells }\end{array}$ & $\begin{array}{l}\text { Human } \\
\text { A549 cells }\end{array}$ & $\begin{array}{l}\text { Human } \\
\text { NPC }\end{array}$ & $\begin{array}{l}\text { Human } \\
\text { BEAS-2B } \\
\text { cells }\end{array}$ \\
\hline $\begin{array}{l}\text { Number of } \\
\text { replicates }\end{array}$ & $n=2$ & $\begin{array}{c}n=3 \\
\text { pooled }\end{array}$ & $n=1$ & $n=3$ & $\begin{array}{c}n>1 \\
\text { pooled }\end{array}$ & $n=3$ & $n=3$ & $n=2$ & $n=3$ \\
\hline $\begin{array}{c}\text { Sequencing } \\
\text { library }\end{array}$ & $\begin{array}{c}\text { ribo- } \\
\text { depleted }\end{array}$ & polyA + & polyA+ & polyA+ & polyA+ & polyA+ & polyA+ & polyA+ & $\begin{array}{c}\text { ribo- } \\
\text { depleted }\end{array}$ \\
\hline $\begin{array}{l}\text { Sequencing } \\
\text { platform }\end{array}$ & HiSeq 2500 & HiSeq 2000 & HiSeq & HiSeq 2000 & $\begin{array}{c}\text { NextSeq } \\
500\end{array}$ & $\begin{array}{l}\text { HiSeq 2000/ } \\
\text { GA II x }\end{array}$ & HiSeq 4000 & $\begin{array}{c}\text { NextSeq } \\
500\end{array}$ & HiSeq 2000 \\
\hline $\begin{array}{c}\text { Reads } \\
\text { features }{ }^{\mathrm{a}}\end{array}$ & $2 \times 101 \mathrm{nt}$ & $2 \times 90 \mathrm{nt}$ & $1 \times 101 \mathrm{nt}$ & $2 \times 100 \mathrm{nt}$ & $2 \times 50 \mathrm{nt}$ & $2 \times 75 \mathrm{nt}$ & $2 \times 90 \mathrm{nt}$ & $2 \times 75 \mathrm{nt}$ & $2 \times 50 \mathrm{nt}$ \\
\hline $\begin{array}{l}\text { Sequencing } \\
\text { depth }\end{array}$ & $\begin{array}{l}>25 \times 10^{6} \\
\text { reads }\end{array}$ & $\begin{array}{l}\sim 26 \times 10^{6} \\
\text { reads* }\end{array}$ & $\begin{array}{c}\sim 130-230 \mathrm{x} \\
10^{6} \text { reads }\end{array}$ & $\begin{array}{c}>40 \times 10^{6} \\
\text { reads }\end{array}$ & NA & $\begin{array}{c}\sim 20-100 \mathrm{x} \\
10^{6} \text { reads }\end{array}$ & $\begin{array}{l}>20 \times 10^{6} \\
\text { reads }\end{array}$ & $\begin{array}{c}\sim 7 \times 10^{6} \\
\text { reads }\end{array}$ & $\begin{array}{c}\sim 30 \times 10^{6} \\
\text { reads }\end{array}$ \\
\hline $\begin{array}{l}\text { Fraction of } \\
\text { viral reads }\end{array}$ & $27 \%$ & $30 \%$ & $22-68 \%$ & NA & NA & NA & $30-40 \%$ & NA & $\sim 5-75 \% * *$ \\
\hline Mapping & $\begin{array}{l}\text { Context } \\
\text { Map }\end{array}$ & TopHat2 & GSNAP & Bowtie2 & TopHat & TopHat & TopHat2 & TopHat2 & TopHat2 \\
\hline $\begin{array}{c}\text { Gene } \\
\text { expression } \\
\text { analysis }\end{array}$ & RPKM & Cufflinks & RPKM & RSEM & NA & Cufflinks & NA & Cufflinks & DESeq2 \\
\hline $\begin{array}{l}\text { Alternative } \\
\text { splicing } \\
\text { analysis }\end{array}$ & $\begin{array}{l}\text { Home- } \\
\text { made } \\
\text { scripts }\end{array}$ & $\begin{array}{l}\text { Cufflinks } \\
\text { ASD } \\
\text { DaPars }\end{array}$ & $\begin{array}{l}\text { Olego } \\
\text { Quantas } \\
\text { MISO }\end{array}$ & RSEM & MISO & $\begin{array}{l}\text { Cufflinks } \\
\text { MISO }\end{array}$ & $\begin{array}{l}\text { ASpli } \\
\text { edgeR }\end{array}$ & $\begin{array}{l}\text { Cufflinks } \\
\text { ASD }\end{array}$ & MISO \\
\hline $\begin{array}{c}\text { Data } \\
\text { availability }\end{array}$ & GSE59717 & NA & GSE74250 & GSE81017 & NA & NA & GSE84285 & GSE78711 & GSE61517 \\
\hline $\begin{array}{l}{ }^{\mathrm{a}} \mathrm{NPC}: \mathrm{Neu} \\
{ }^{\mathrm{b}} \text { nt: nucle } \\
{ }^{\mathrm{c}} \mathrm{NA} \text { : not a } \\
{ }^{*} \text { number }\end{array}$ & $\begin{array}{l}\text { ral Progeni } \\
\text { tide } \\
\text { vailable } \\
\text { of reads for }\end{array}$ & $\begin{array}{l}\text { Cells } \\
\text { e poole }\end{array}$ & ples, * & onding & he vir & ain and & -point & & \\
\hline
\end{tabular}


426 Figure legends.

427

428 Figure 1. Virus-spliceosome protein-protein interaction network.

429 A. Summary of virus-spliceosome protein-protein interactions, as recorded in the VirHostNet 430 database, January release 2018 [23]. For each viral family, the number of viral species (as 431 defined by the International Committee on Taxonomy of Viruses and the National Center for 432 Biological Information or NCBI) and viral proteins (as defined by the NCBI Reference 433 Sequence and the UniProt databases) reported to interact with at least one cellular 434 spliceosomal factor (among the list of 244 factors defined in [123]) is indicated. The number 435 of viral proteins obtained upon merging of homologous proteins derived from different 436 strains or isolates of a single viral species, grouped thereafter under the name "viral proteins 437 types" and represented as a single node in B, are indicated into brackets.

438 B and C. Interaction network between viral proteins (B) or viral species (C) and cellular 439 spliceosomal proteins. The network was built with Cytoscape (version 3.2.1). Nodes and 440 edges between nodes represent protein and protein-protein interactions, respectively. Core 441 and regulatory spliceosomal factors are represented by square and triangular black nodes, 442 respectively. B. Viral proteins types, as defined in A, are represented by colored nodes (the 443 color code is according to the Table in A). The size of the viral protein nodes is proportional 444 to their degree of connectivity (i.e. the number of interacting partners of a protein) and the 445 layout is done according to their centrality in the network. C. Viral species are represented 446 by colored nodes (the color code is according to the Table in A). The size of the spliceosomal 447 factor nodes is proportional to their degree of connectivity and the layout is done according 448 to their centrality. The five spliceosomal factors showing the highest degree of connectivity 449 (interaction with 11 to 15 distinct viral species) are indicated with a white star and edges 450 representing their protein-protein interactions with viral species are highlighted in red.

451

452 Figure 2. Direct and indirect mechanisms for viral-induced splicing alterations.

453 Red arrows represent viral manipulation of the splicing machinery and the resulting AS 454 changes, which have in turn the potential to modulate innate immunity $[16,95]$ or apoptosis 455 [124]. Blue arrows represent viral-induced cell damages and innate immune responses and 456 the subsequent AS changes in the infected cell [40-43]. Grey arrows represent viral-induced 
457 B- and T-cell immune responses, which are subject to AS-mediated regulation [38-40]. UPR:

458 Unfolded Protein Response. DDR : DNA Damage Response.

459

460

461 
464 1. Fica SM, Nagai K. Cryo-electron microscopy snapshots of the spliceosome: structural insights 465 into a dynamic ribonucleoprotein machine. Nat Struct Mol Biol. 2017;24(10):791-9. Epub 466 2017/10/06. doi: 10.1038/nsmb.3463. PubMed PMID: 28981077.

467 2. Papasaikas P, Valcarcel J. The Spliceosome: The Ultimate RNA Chaperone and Sculptor.

468 Trends Biochem Sci. 2016;41(1):33-45. Epub 2015/12/20. doi: 10.1016/j.tibs.2015.11.003. PubMed 469 PMID: 26682498.

470 3. Lee Y, Rio DC. Mechanisms and Regulation of Alternative Pre-mRNA Splicing. Annu Rev 471 Biochem. 2015;84:291-323. Epub 2015/03/19. doi: 10.1146/annurev-biochem-060614-034316. 472 PubMed PMID: 25784052; PubMed Central PMCID: PMCPMC4526142.

473 4. Sakharkar MK, Chow VT, Kangueane P. Distributions of exons and introns in the human 474 genome. In Silico Biol. 2004;4(4):387-93. Epub 2004/06/26. PubMed PMID: 15217358.

475 5. Li X, Yang L, Chen LL. The Biogenesis, Functions, and Challenges of Circular RNAs. Mol Cell. 476 2018;71(3):428-42. Epub 2018/07/31. doi: 10.1016/j.molcel.2018.06.034. PubMed PMID: 30057200.

477 6. Wang M, Yu F, Wu W, Zhang Y, Chang W, Ponnusamy M, et al. Circular RNAs: A novel type of 478 non-coding RNA and their potential implications in antiviral immunity. Int J Biol Sci.

479 2017;13(12):1497-506. Epub 2017/12/13. doi: 10.7150/ijbs.22531. PubMed PMID: 29230098; 480 PubMed Central PMCID: PMCPMC5723916.

481 7. Kornblihtt AR, Schor IE, Allo M, Dujardin G, Petrillo E, Munoz MJ. Alternative splicing: a 482 pivotal step between eukaryotic transcription and translation. Nat Rev Mol Cell Biol. 2013;14(3):153483 65. Epub 2013/02/07. doi: 10.1038/nrm3525. PubMed PMID: 23385723.

484 8. Richards AL, Watza D, Findley A, Alazizi A, Wen X, Pai AA, et al. Environmental perturbations 485 lead to extensive directional shifts in RNA processing. PLoS Genet. 2017;13(10):e1006995. Epub 486 2017/10/13. doi: 10.1371/journal.pgen.1006995. PubMed PMID: 29023442; PubMed Central PMCID: 487 PMCPMC5667937.

488 9. Harwig A, Landick R, Berkhout B. The Battle of RNA Synthesis: Virus versus Host. Viruses. 489 2017;9(10). Epub 2017/10/27. doi: 10.3390/v9100309. PubMed PMID: 29065472; PubMed Central 490 PMCID: PMCPMC5691660.

491 10. Herbert KM, Nag A. A Tale of Two RNAs during Viral Infection: How Viruses Antagonize 492 mRNAs and Small Non-Coding RNAs in The Host Cell. Viruses. 2016;8(6). Epub 2016/06/09. doi: 493 10.3390/v8060154. PubMed PMID: 27271653; PubMed Central PMCID: PMCPMC4926174.

494 11. Rivas HG, Schmaling SK, Gaglia MM. Shutoff of Host Gene Expression in Influenza A Virus and 495 Herpesviruses: Similar Mechanisms and Common Themes. Viruses. 2016;8(4):102. Epub 2016/04/20. 496 doi: 10.3390/v8040102. PubMed PMID: 27092522; PubMed Central PMCID: PMCPMC4848596.

497 12. De Maio FA, Risso G, Iglesias NG, Shah P, Pozzi B, Gebhard LG, et al. The Dengue Virus NS5 498 Protein Intrudes in the Cellular Spliceosome and Modulates Splicing. PLoS Pathog.

499 2016;12(8):e1005841. Epub 2016/08/31. doi: 10.1371/journal.ppat.1005841. PubMed PMID:

500 27575636; PubMed Central PMCID: PMCPMC5004807.

501 13. Twyffels L, Gueydan C, Kruys V. Shuttling SR proteins: more than splicing factors. FEBS J.

502 2011;278(18):3246-55. Epub 2011/07/29. doi: 10.1111/j.1742-4658.2011.08274.x. PubMed PMID:

50321794093.

504 14. Cohen S, Etingov I, Pante N. Effect of viral infection on the nuclear envelope and nuclear pore 505 complex. Int Rev Cell Mol Biol. 2012;299:117-59. Epub 2012/09/11. doi: 10.1016/B978-0-12-394310506 1.00003-5. PubMed PMID: 22959302.

507 15. Avota E, Harms H, Schneider-Schaulies S. Measles virus induces expression of SIP110, a 508 constitutively membrane clustered lipid phosphatase, which inhibits T cell proliferation. Cell 509 Microbiol. 2006;8(11):1826-39. Epub 2006/07/11. doi: 10.1111/j.1462-5822.2006.00752.x. PubMed 510 PMID: 16824039. 

Restricting Hepatitis C Virus Infection through the RIG-I/MDA5 Pathway. J Virol. 2015;89(13):660818. Epub 2015/04/17. doi: 10.1128/JVI.00364-15. PubMed PMID: 25878102; PubMed Central PMCID: PMCPMC4468487.

17. Howard JM, Sanford JR. The RNAissance family: SR proteins as multifaceted regulators of gene expression. Wiley Interdiscip Rev RNA. 2015;6(1):93-110. Epub 2014/08/27. doi: 10.1002/wrna.1260. PubMed PMID: 25155147; PubMed Central PMCID: PMCPMC4268343. 18. Wojcechowskyj JA, Didigu CA, Lee JY, Parrish NF, Sinha R, Hahn BH, et al. Quantitative phosphoproteomics reveals extensive cellular reprogramming during HIV-1 entry. Cell Host Microbe. 2013;13(5):613-23. Epub 2013/05/21. doi: 10.1016/j.chom.2013.04.011. PubMed PMID: 23684312; PubMed Central PMCID: PMCPMC4104530.

520

19. Lapek JD, Jr., Lewinski MK, Wozniak JM, Guatelli J, Gonzalez DJ. Quantitative Temporal Viromics of an Inducible HIV-1 Model Yields Insight to Global Host Targets and Phospho-Dynamics Associated with Protein Vpr. Mol Cell Proteomics. 2017;16(8):1447-61. Epub 2017/06/14. doi: 10.1074/mcp.M116.066019. PubMed PMID: 28606917; PubMed Central PMCID: PMCPMC5546197. 20. Estmer Nilsson C, Petersen-Mahrt S, Durot C, Shtrichman R, Krainer AR, Kleinberger T, et al. The adenovirus E4-ORF4 splicing enhancer protein interacts with a subset of phosphorylated SR proteins. EMBO J. 2001;20(4):864-71. Epub 2001/02/17. doi: 10.1093/emboj/20.4.864. PubMed PMID: 11179230; PubMed Central PMCID: PMCPMC145406. type $1 \mathrm{E} 1^{\wedge} \mathrm{E} 4$ protein is a potent inhibitor of the serine-arginine (SR) protein kinase SRPK1 and inhibits phosphorylation of host SR proteins and of the viral transcription and replication regulator E2. J Virol. 2014;88(21):12599-611. Epub 2014/08/22. doi: 10.1128/JVI.02029-14. PubMed PMID: 25142587; PubMed Central PMCID: PMCPMC4248925.

22. Sciabica KS, Dai QJ, Sandri-Goldin RM. ICP27 interacts with SRPK1 to mediate HSV splicing inhibition by altering SR protein phosphorylation. EMBO J. 2003;22(7):1608-19. Epub 2003/03/28. doi: 10.1093/emboj/cdg166. PubMed PMID: 12660167; PubMed Central PMCID: PMCPMC152910. 23. Guirimand T, Delmotte S, Navratil V. VirHostNet 2.0: surfing on the web of virus/host molecular interactions data. Nucleic Acids Res. 2015;43(Database issue):D583-7. Epub 2014/11/14. doi: 10.1093/nar/gku1121. PubMed PMID: 25392406; PubMed Central PMCID: PMCPMC4383936. of the Cell Splicing Protein SRSF2. J Virol. 2017;91(7). Epub 2017/01/13. doi: 10.1128/JVI.02488-16. PubMed PMID: 28077658; PubMed Central PMCID: PMCPMC5355601.

544 25. Barnhart MD, Moon SL, Emch AW, Wilusz CJ, Wilusz J. Changes in cellular mRNA stability, splicing, and polyadenylation through HuR protein sequestration by a cytoplasmic RNA virus. Cell Rep. 2013;5(4):909-17. Epub 2013/11/12. doi: 10.1016/j.celrep.2013.10.012. PubMed PMID: 24210824; PubMed Central PMCID: PMCPMC3849337.

26. Batra R, Stark TJ, Clark E, Belzile JP, Wheeler EC, Yee BA, et al. RNA-binding protein CPEB1 remodels host and viral RNA landscapes. Nat Struct Mol Biol. 2016;23(12):1101-10. Epub 2016/11/01. doi: 10.1038/nsmb.3310. PubMed PMID: 27775709; PubMed Central PMCID: PMCPMC5140759.

27. Hu B, Li X, Huo Y, Yu Y, Zhang $Q$, Chen G, et al. Cellular responses to HSV-1 infection are linked to specific types of alterations in the host transcriptome. Sci Rep. 2016;6:28075. Epub 2016/06/30. doi: 10.1038/srep28075. PubMed PMID: 27354008; PubMed Central PMCID: PMCPMC4926211.

556 28. Rutkowski AJ, Erhard F, L'Hernault A, Bonfert T, Schilhabel M, Crump C, et al. Widespread 
560 29. Boudreault S, Martenon-Brodeur C, Caron M, Garant JM, Tremblay MP, Armero VE, et al. 561 Global Profiling of the Cellular Alternative RNA Splicing Landscape during Virus-Host Interactions. 562 PLoS One. 2016;11(9):e0161914. Epub 2016/09/07. doi: 10.1371/journal.pone.0161914. PubMed 563 PMID: 27598998; PubMed Central PMCID: PMCPMC5012649.

564 30. Sessions OM, Tan Y, Goh KC, Liu Y, Tan P, Rozen S, et al. Host cell transcriptome profile during 565 wild-type and attenuated dengue virus infection. PLoS NegI Trop Dis. 2013;7(3):e2107. Epub 566 2013/03/22. doi: 10.1371/journal.pntd.0002107. PubMed PMID: 23516652; PubMed Central PMCID: 567 PMCPMC3597485.

568 31. Hu B, Huo Y, Yang L, Chen G, Luo M, Yang J, et al. ZIKV infection effects changes in gene 569 splicing, isoform composition and IncRNA expression in human neural progenitor cells. Virol J. 570 2017;14(1):217. Epub 2017/11/09. doi: 10.1186/s12985-017-0882-6. PubMed PMID: 29116029; 571 PubMed Central PMCID: PMCPMC5688814.

572 32. Fabozzi G, Oler AJ, Liu P, Chen Y, Mindaye S, Dolan MA, et al. Strand-Specific Dual RNA 573 Sequencing of Bronchial Epithelial Cells Infected with Influenza A/H3N2 Viruses Reveals Splicing of 574 Gene Segment 6 and Novel Host-Virus Interactions. J Virol. 2018;92(17). Epub 2018/07/07. doi: 575 10.1128/JVI.00518-18. PubMed PMID: 29976658; PubMed Central PMCID: PMCPMC6096831.

576 33. Wang ET, Sandberg R, Luo S, Khrebtukova I, Zhang L, Mayr C, et al. Alternative isoform 577 regulation in human tissue transcriptomes. Nature. 2008;456(7221):470-6. Epub 2008/11/04. doi: 578 10.1038/nature07509. PubMed PMID: 18978772; PubMed Central PMCID: PMCPMC2593745.

579 34. Rekosh D, Hammarskjold ML. Intron retention in viruses and cellular genes: Detention, 580 border controls and passports. Wiley Interdiscip Rev RNA. 2018;9(3):e1470. Epub 2018/03/07. doi: 581 10.1002/wrna.1470. PubMed PMID: 29508942; PubMed Central PMCID: PMCPMC5910242.

582 35. Zhang L, Wang J, Munoz-Moreno R, Kim M, Sakthivel R, Mo W, et al. Influenza Virus NS1 583 Protein RNA-Interactome Reveals Intron Targeting. J Virol. 2018. Epub 2018/09/28. doi: 584 10.1128/JVI.01634-18. PubMed PMID: 30258002.

585 36. Li X, Liu CX, Xue W, Zhang Y, Jiang S, Yin QF, et al. Coordinated circRNA Biogenesis and 586 Function with NF90/NF110 in Viral Infection. Mol Cell. 2017;67(2):214-27 e7. Epub 2017/06/20. doi: 587 10.1016/j.molcel.2017.05.023. PubMed PMID: 28625552.

588 37. Shi J, Hu N, Mo L, Zeng Z, Sun J, Hu Y. Deep RNA Sequencing Reveals a Repertoire of Human 589 Fibroblast Circular RNAs Associated with Cellular Responses to Herpes Simplex Virus 1 Infection. Cell 590 Physiol Biochem. 2018;47(5):2031-45. Epub 2018/07/05. doi: 10.1159/000491471. PubMed PMID: 59129972822.

592 38. Chang MX, Zhang J. Alternative Pre-mRNA Splicing in Mammals and Teleost Fish: A Effective 593 Strategy for the Regulation of Immune Responses Against Pathogen Infection. Int J Mol Sci.

594 2017;18(7). Epub 2017/07/18. doi: 10.3390/ijms18071530. PubMed PMID: 28714877; PubMed 595 Central PMCID: PMCPMC5536018.

596 39. Martinez NM, Lynch KW. Control of alternative splicing in immune responses: many 597 regulators, many predictions, much still to learn. Immunol Rev. 2013;253(1):216-36. Epub 598 2013/04/05. doi: 10.1111/imr.12047. PubMed PMID: 23550649; PubMed Central PMCID: 599 PMCPMC3621013.

600 40. Schaub A, Glasmacher E. Splicing in immune cells-mechanistic insights and emerging topics. 601 Int Immunol. 2017;29(4):173-81. Epub 2017/05/13. doi: 10.1093/intimm/dxx026. PubMed PMID:

602 28498981; PubMed Central PMCID: PMCPMC5890895.

603 41. Paronetto MP, Passacantilli I, Sette C. Alternative splicing and cell survival: from tissue 604 homeostasis to disease. Cell Death Differ. 2016;23(12):1919-29. Epub 2016/10/01. doi: 605 10.1038/cdd.2016.91. PubMed PMID: 27689872; PubMed Central PMCID: PMCPMC5136496.

606 42. Shkreta L, Chabot B. The RNA Splicing Response to DNA Damage. Biomolecules. 607 2015;5(4):2935-77. Epub 2015/11/04. doi: 10.3390/biom5042935. PubMed PMID: 26529031; 608 PubMed Central PMCID: PMCPMC4693264. 
609

610

611

612

613

614

615

616

617

618

619

620

621

622

623

624

625

626

627

628

629

630

631

632

633

634

635

636

637

638

639

640

641

642

643

644

645

646

647

648

649

650

651

652

653

654

655

656

657

658

43. Tsalikis J, Pan Q, Tattoli I, Maisonneuve C, Blencowe BJ, Philpott DJ, et al. The transcriptional and splicing landscape of intestinal organoids undergoing nutrient starvation or endoplasmic reticulum stress. BMC Genomics. 2016;17:680. Epub 2016/08/27. doi: 10.1186/s12864-016-2999-1. PubMed PMID: 27561422; PubMed Central PMCID: PMCPMC5000506.

44. Tang S, Patel A, Krause PR. Herpes simplex virus ICP27 regulates alternative pre-mRNA polyadenylation and splicing in a sequence-dependent manner. Proc Natl Acad Sci U S A. 2016;113(43):12256-61. Epub 2016/10/30. doi: 10.1073/pnas.1609695113. PubMed PMID: 27791013; PubMed Central PMCID: PMCPMC5087043.

45. Bauer DLV, Tellier M, Martinez-Alonso M, Nojima T, Proudfoot NJ, Murphy S, et al. Influenza Virus Mounts a Two-Pronged Attack on Host RNA Polymerase II Transcription. Cell Rep. 2018;23(7):2119-29 e3. Epub 2018/05/17. doi: 10.1016/j.celrep.2018.04.047. PubMed PMID: 29768209 ; PubMed Central PMCID: PMCPMC5972227.

46. Heinz S, Texari L, Hayes MGB, Urbanowski M, Chang MW, Givarkes N, et al. Transcription Elongation Can Affect Genome 3D Structure. Cell. 2018;174(6):1522-36 e22. Epub 2018/08/28. doi: 10.1016/j.cell.2018.07.047. PubMed PMID: 30146161; PubMed Central PMCID: PMCPMC6130916.

47. Zhao N, Sebastiano V, Moshkina N, Mena N, Hultquist J, Jimenez-Morales D, et al. Influenza virus infection causes global RNAPII termination defects. Nat Struct Mol Biol. 2018;25(9):885-93. Epub 2018/09/05. doi: 10.1038/s41594-018-0124-7. PubMed PMID: 30177761.

48. Love MI, Huber W, Anders S. Moderated estimation of fold change and dispersion for RNAseq data with DESeq2. Genome Biol. 2014;15(12):550. Epub 2014/12/18. doi: 10.1186/s13059-0140550-8. PubMed PMID: 25516281; PubMed Central PMCID: PMCPMC4302049.

49. Westermann AJ, Barquist L, Vogel J. Resolving host-pathogen interactions by dual RNA-seq. PLoS Pathog. 2017;13(2):e1006033. Epub 2017/02/17. doi: 10.1371/journal.ppat.1006033. PubMed PMID: 28207848; PubMed Central PMCID: PMCPMC5313147.

50. Cristinelli S, Ciuffi A. The use of single-cell RNA-Seq to understand virus-host interactions. Curr Opin Virol. 2018;29:39-50. Epub 2018/03/21. doi: 10.1016/j.coviro.2018.03.001. PubMed PMID: 29558678.

51. Russell AB, Trapnell C, Bloom JD. Extreme heterogeneity of influenza virus infection in single cells. Elife. 2018;7. Epub 2018/02/17. doi: 10.7554/eLife.32303. PubMed PMID: 29451492; PubMed Central PMCID: PMCPMC5826275.

52. Steuerman Y, Cohen M, Peshes-Yaloz N, Valadarsky L, Cohn O, David E, et al. Dissection of Influenza Infection In Vivo by Single-Cell RNA Sequencing. Cell Syst. 2018;6(6):679-91 e4. Epub 2018/06/11. doi: 10.1016/j.cels.2018.05.008. PubMed PMID: 29886109.

53. Huang $Y$, Sanguinetti G. BRIE: transcriptome-wide splicing quantification in single cells. Genome Biol. 2017;18(1):123. Epub 2017/06/29. doi: 10.1186/s13059-017-1248-5. PubMed PMID: 28655331; PubMed Central PMCID: PMCPMC5488362.

54. Song Y, Botvinnik OB, Lovci MT, Kakaradov B, Liu P, Xu JL, et al. Single-Cell Alternative Splicing Analysis with Expedition Reveals Splicing Dynamics during Neuron Differentiation. Mol Cell. 2017;67(1):148-61 e5. Epub 2017/07/05. doi: 10.1016/j.molcel.2017.06.003. PubMed PMID: 28673540; PubMed Central PMCID: PMCPMC5540791.

55. Vallejos CA, Risso D, Scialdone A, Dudoit S, Marioni JC. Normalizing single-cell RNA sequencing data: challenges and opportunities. Nat Methods. 2017;14(6):565-71. Epub 2017/05/16. doi: 10.1038/nmeth.4292. PubMed PMID: 28504683; PubMed Central PMCID: PMCPMC5549838.

56. Schobel A, Rosch $\mathrm{K}$, Herker E. Functional innate immunity restricts Hepatitis $\mathrm{C}$ Virus infection in induced pluripotent stem cell-derived hepatocytes. Sci Rep. 2018;8(1):3893. Epub 2018/03/03. doi: 10.1038/s41598-018-22243-7. PubMed PMID: 29497123; PubMed Central PMCID: PMCPMC5832748.

57. Ramani S, Crawford SE, Blutt SE, Estes MK. Human organoid cultures: transformative new tools for human virus studies. Curr Opin Virol. 2018;29:79-86. Epub 2018/04/16. doi: 10.1016/j.coviro.2018.04.001. PubMed PMID: 29656244; PubMed Central PMCID: PMCPMC5944856. 
659 58. Ljungberg K, McBrayer A, Camp JV, Chu YK, Tapp R, Noah DL, et al. Host gene expression 660 signatures discriminate between ferrets infected with genetically similar H1N1 strains. PLoS One. 661 2012;7(7):e40743. Epub 2012/07/19. doi: 10.1371/journal.pone.0040743. PubMed PMID: 22808249; 662 PubMed Central PMCID: PMCPMC3396591.

663 59. Holzer M, Krahling V, Amman F, Barth E, Bernhart SH, Carmelo VA, et al. Differential 664 transcriptional responses to Ebola and Marburg virus infection in bat and human cells. Sci Rep. 665 2016;6:34589. Epub 2016/10/08. doi: 10.1038/srep34589. PubMed PMID: 27713552; PubMed 666 Central PMCID: PMCPMC5054393.

667 60. Liu X, Speranza E, Munoz-Fontela C, Haldenby S, Rickett NY, Garcia-Dorival I, et al.

668 Transcriptomic signatures differentiate survival from fatal outcomes in humans infected with Ebola

669 virus. Genome Biol. 2017;18(1):4. Epub 2017/01/20. doi: 10.1186/s13059-016-1137-3. PubMed

670 PMID: 28100256; PubMed Central PMCID: PMCPMC5244546.

671 61. Gliddon HD, Herberg JA, Levin M, Kaforou M. Genome-wide host RNA signatures of infectious 672 diseases: discovery and clinical translation. Immunology. 2018;153(2):171-8. Epub 2017/09/19. doi:

673 10.1111/imm.12841. PubMed PMID: 28921535; PubMed Central PMCID: PMCPMC5765383.

674 62. Badr E, ElHefnawi M, Heath LS. Computational Identification of Tissue-Specific Splicing 675 Regulatory Elements in Human Genes from RNA-Seq Data. PLoS One. 2016;11(11):e0166978. Epub 676 2016/11/20. doi: 10.1371/journal.pone.0166978. PubMed PMID: 27861625; PubMed Central PMCID: 677 PMCPMC5115852.

678 63. Li J, Yu P. Genome-wide transcriptome analysis identifies alternative splicing regulatory 679 network and key splicing factors in mouse and human psoriasis. Sci Rep. 2018;8(1):4124. Epub 680 2018/03/09. doi: 10.1038/s41598-018-22284-y. PubMed PMID: 29515135; PubMed Central PMCID: 681 PMCPMC5841439.

682 64. Chasman D, Walters KB, Lopes TJ, Eisfeld AJ, Kawaoka Y, Roy S. Integrating Transcriptomic 683 and Proteomic Data Using Predictive Regulatory Network Models of Host Response to Pathogens. 684 PLoS Comput Biol. 2016;12(7):e1005013. Epub 2016/07/13. doi: 10.1371/journal.pcbi.1005013. 685 PubMed PMID: 27403523; PubMed Central PMCID: PMCPMC4942116.

686 65. Sychev ZE, Hu A, DiMaio TA, Gitter A, Camp ND, Noble WS, et al. Integrated systems biology 687 analysis of KSHV latent infection reveals viral induction and reliance on peroxisome mediated lipid 688 metabolism. PLoS Pathog. 2017;13(3):e1006256. Epub 2017/03/04. doi:

689 10.1371/journal.ppat.1006256. PubMed PMID: 28257516; PubMed Central PMCID:

690 PMCPMC5352148.

691 66. Tisoncik-Go J, Gasper DJ, Kyle JE, Eisfeld AJ, Selinger C, Hatta M, et al. Integrated Omics 692 Analysis of Pathogenic Host Responses during Pandemic H1N1 Influenza Virus Infection: The Crucial 693 Role of Lipid Metabolism. Cell Host Microbe. 2016;19(2):254-66. Epub 2016/02/13. doi:

694 10.1016/j.chom.2016.01.002. PubMed PMID: 26867183; PubMed Central PMCID: PMCPMC5271177.

695 67. Eisfeld AJ, Halfmann PJ, Wendler JP, Kyle JE, Burnum-Johnson KE, Peralta Z, et al. Multi696 platform 'Omics Analysis of Human Ebola Virus Disease Pathogenesis. Cell Host Microbe. 697 2017;22(6):817-29 e8. Epub 2017/11/21. doi: 10.1016/j.chom.2017.10.011. PubMed PMID: 698 29154144; PubMed Central PMCID: PMCPMC5730472.

699 68. van Kampen AH, Moerland PD. Taking Bioinformatics to Systems Medicine. Methods Mol 700 Biol. 2016;1386:17-41. Epub 2015/12/18. doi: 10.1007/978-1-4939-3283-2_2. PubMed PMID: 70126677177.

702 69. Haynes WA, Tomczak A, Khatri P. Gene annotation bias impedes biomedical research. Sci 703 Rep. 2018;8(1):1362. Epub 2018/01/24. doi: 10.1038/s41598-018-19333-x. PubMed PMID: 704 29358745; PubMed Central PMCID: PMCPMC5778030.

705 70. Liu Y, Gonzalez-Porta M, Santos S, Brazma A, Marioni JC, Aebersold R, et al. Impact of 706 Alternative Splicing on the Human Proteome. Cell Rep. 2017;20(5):1229-41. Epub 2017/08/03. doi: 707 10.1016/j.celrep.2017.07.025. PubMed PMID: 28768205; PubMed Central PMCID: PMCPMC5554779. 

Complexity. Trends Biochem Sci. 2017;42(2):98-110. Epub 2016/10/08. doi: 10.1016/j.tibs.2016.08.008. PubMed PMID: 27712956. protein features encoded by alternative exons using Exon Ontology. Genome Res. 2017;27(6):108797. Epub 2017/04/20. doi: 10.1101/gr.212696.116. PubMed PMID: 28420690; PubMed Central

714 PMCID: PMCPMC5453322.

715 73. Li HD, Menon R, Omenn GS, Guan Y. The emerging era of genomic data integration for 716 analyzing splice isoform function. Trends Genet. 2014;30(8):340-7. Epub 2014/06/22. doi:

717 10.1016/j.tig.2014.05.005. PubMed PMID: 24951248; PubMed Central PMCID: PMCPMC4112133.

718

719

720

721

722

723

724

725

726

727

728

729

730

731

732

733

734

735

736

737

738

739

740

741

742

743

744

745

746

747

748

749

750

751

752

753

754

755

756

74. Li W, Liu CC, Kang S, Li JR, Tseng YT, Zhou XJ. Pushing the annotation of cellular activities to a higher resolution: Predicting functions at the isoform level. Methods. 2016;93:110-8. Epub 2015/08/05. doi: 10.1016/j.ymeth.2015.07.016. PubMed PMID: 26238263.

75. Corominas R, Yang X, Lin GN, Kang S, Shen Y, Ghamsari L, et al. Protein interaction network of alternatively spliced isoforms from brain links genetic risk factors for autism. Nat Commun. 2014;5:3650. Epub 2014/04/12. doi: 10.1038/ncomms4650. PubMed PMID: 24722188; PubMed Central PMCID: PMCPMC3996537.

76. Yang X, Coulombe-Huntington J, Kang S, Sheynkman GM, Hao T, Richardson A, et al. Widespread Expansion of Protein Interaction Capabilities by Alternative Splicing. Cell. 2016;164(4):805-17. Epub 2016/02/13. doi: 10.1016/j.cell.2016.01.029. PubMed PMID: 26871637; PubMed Central PMCID: PMCPMC4882190.

77. Diner BA, Li T, Greco TM, Crow MS, Fuesler JA, Wang J, et al. The functional interactome of PYHIN immune regulators reveals IFIX is a sensor of viral DNA. Mol Syst Biol. 2015;11(1):787. Epub 2015/02/11. doi: 10.15252/msb.20145808. PubMed PMID: 25665578; PubMed Central PMCID: PMCPMC4358659.

78. Ghosh S, Kumar GV, Basu A, Banerjee A. Graph theoretic network analysis reveals protein pathways underlying cell death following neurotropic viral infection. Sci Rep. 2015;5:14438. Epub 2015/09/26. doi: 10.1038/srep14438. PubMed PMID: 26404759; PubMed Central PMCID: PMCPMC4585883.

79. Gregoire IP, Richetta C, Meyniel-Schicklin L, Borel S, Pradezynski F, Diaz O, et al. IRGM is a common target of RNA viruses that subvert the autophagy network. PLoS Pathog. 2011;7(12):e1002422. Epub 2011/12/17. doi: 10.1371/journal.ppat.1002422. PubMed PMID: 22174682; PubMed Central PMCID: PMCPMC3234227.

80. Akerman M, Fregoso OI, Das S, Ruse C, Jensen MA, Pappin DJ, et al. Differential connectivity of splicing activators and repressors to the human spliceosome. Genome Biol. 2015;16:119. Epub 2015/06/07. doi: 10.1186/s13059-015-0682-5. PubMed PMID: 26047612; PubMed Central PMCID: PMCPMC4502471.

81. Pires MM, Cantor M, Guimaraes PR, de Aguiar MA, Dos Reis SF, Coltri PP. The network organization of protein interactions in the spliceosome is reproduced by the simple rules of food-web models. Sci Rep. 2015;5:14865. Epub 2015/10/08. doi: 10.1038/srep14865. PubMed PMID: 26443080; PubMed Central PMCID: PMCPMC4595644.

82. Jha A, Gazzara MR, Barash Y. Integrative deep models for alternative splicing. Bioinformatics. 2017;33(14):i274-i82. Epub 2017/09/09. doi: 10.1093/bioinformatics/btx268. PubMed PMID: 28882000; PubMed Central PMCID: PMCPMC5870723.

83. Marazzi I, Garcia-Sastre A. Interference of viral effector proteins with chromatin, transcription, and the epigenome. Curr Opin Microbiol. 2015;26:123-9. Epub 2015/08/02. doi: 10.1016/j.mib.2015.06.009. PubMed PMID: 26232586.

84. Menachery VD, Schafer A, Burnum-Johnson KE, Mitchell HD, Eisfeld AJ, Walters KB, et al. MERS-CoV and H5N1 influenza virus antagonize antigen presentation by altering the epigenetic 
landscape. Proc Natl Acad Sci U S A. 2018;115(5):E1012-E21. Epub 2018/01/18. doi: 10.1073/pnas.1706928115. PubMed PMID: 29339515; PubMed Central PMCID: PMCPMC5798318. 85. Gonzales-van Horn SR, Sarnow P. Making the Mark: The Role of Adenosine Modifications in the Life Cycle of RNA Viruses. Cell Host Microbe. 2017;21(6):661-9. Epub 2017/06/16. doi: 10.1016/j.chom.2017.05.008. PubMed PMID: 28618265; PubMed Central PMCID: PMCPMC5555051. 86. Knuckles $P$, Buhler $M$. Adenosine methylation as a molecular imprint defining the fate of RNA. FEBS Lett. 2018. Epub 2018/05/22. doi: 10.1002/1873-3468.13107. PubMed PMID: 29782652.

87. Naftelberg S, Schor IE, Ast G, Kornblihtt AR. Regulation of alternative splicing through coupling with transcription and chromatin structure. Annu Rev Biochem. 2015;84:165-98. Epub 2015/06/04. doi: 10.1146/annurev-biochem-060614-034242. PubMed PMID: 26034889.

88. Park E, Pan Z, Zhang Z, Lin L, Xing Y. The Expanding Landscape of Alternative Splicing Variation in Human Populations. Am J Hum Genet. 2018;102(1):11-26. Epub 2018/01/06. doi: 10.1016/j.ajhg.2017.11.002. PubMed PMID: 29304370; PubMed Central PMCID: PMCPMC5777382. 89. Baker SF, Ledwith MP, Mehle A. Differential Splicing of ANP32A in Birds Alters Its Ability to Stimulate RNA Synthesis by Restricted Influenza Polymerase. Cell Rep. 2018;24(10):2581-8 e4. Epub 2018/09/06. doi: 10.1016/j.celrep.2018.08.012. PubMed PMID: 30184493; PubMed Central PMCID: PMCPMC6157632.

90. Ibrahim B, McMahon DP, Hufsky F, Beer M, Deng L, Mercier PL, et al. A new era of virus bioinformatics. Virus Res. 2018;251:86-90. Epub 2018/05/12. doi: 10.1016/j.virusres.2018.05.009. PubMed PMID: 29751021.

777 91. De Arras L, Laws R, Leach SM, Pontis K, Freedman JH, Schwartz DA, et al. Comparative 778 genomics RNAi screen identifies Eftud2 as a novel regulator of innate immunity. Genetics.

779 2014;197(2):485-96. Epub 2013/12/24. doi: 10.1534/genetics.113.160499. PubMed PMID: 24361939; 780 PubMed Central PMCID: PMCPMC4063909.

781 92. O'Connor BP, Danhorn T, De Arras L, Flatley BR, Marcus RA, Farias-Hesson E, et al. Regulation 782 783 of toll-like receptor signaling by the SF3a mRNA splicing complex. PLoS Genet. 2015;11(2):e1004932. Epub 2015/02/07. doi: 10.1371/journal.pgen.1004932. PubMed PMID: 25658809; PubMed Central PMCID: PMCPMC4450051.

93. Gack MU, Kirchhofer A, Shin YC, Inn KS, Liang C, Cui S, et al. Roles of RIG-I N-terminal tandem CARD and splice variant in TRIM25-mediated antiviral signal transduction. Proc Natl Acad Sci U S A. 2008;105(43):16743-8. Epub 2008/10/25. doi: 10.1073/pnas.0804947105. PubMed PMID: 18948594; PubMed Central PMCID: PMCPMC2575490.

94. Wang PH, Fung SY, Gao WW, Deng JJ, Cheng Y, Chaudhary V, et al. A novel transcript isoform of STING that sequesters CGAMP and dominantly inhibits innate nucleic acid sensing. Nucleic Acids Res. 2018;46(8):4054-71. Epub 2018/03/17. doi: 10.1093/nar/gky186. PubMed PMID: 29547894; PubMed Central PMCID: PMCPMC5934658.

95. Deng W, Shi M, Han M, Zhong J, Li Z, Li W, et al. Negative regulation of virus-triggered IFNbeta signaling pathway by alternative splicing of TBK1. J Biol Chem. 2008;283(51):35590-7. Epub 2008/11/04. doi: 10.1074/jbc.M805775200. PubMed PMID: 18977754.

96. Lakhdari O, McAllister CS, Wang M, Minev I, Prince LS, Eckmann L, et al. TLR3 signaling is downregulated by a MAVS isoform in epithelial cells. Cell Immunol. 2016;310:205-10. Epub 2016/09/07. doi: 10.1016/j.cellimm.2016.08.010. PubMed PMID: 27593154; PubMed Central PMCID: PMCPMC5125873.

800 97. Qi N, Shi Y, Zhang R, Zhu W, Yuan B, Li X, et al. Multiple truncated isoforms of MAVS prevent 801 its spontaneous aggregation in antiviral innate immune signalling. Nat Commun. 2017;8:15676. Epub 802 803

804 98. Diaz-Munoz MD, Bell SE, Fairfax K, Monzon-Casanova E, Cunningham AF, Gonzalez-Porta M, 805 et al. The RNA-binding protein HuR is essential for the B cell antibody response. Nat Immunol. 
2015;16(4):415-25. Epub 2015/02/24. doi: 10.1038/ni.3115. PubMed PMID: 25706746; PubMed Central PMCID: PMCPMC4479220.

99. Enders A, Short A, Miosge LA, Bergmann H, Sontani Y, Bertram EM, et al. Zinc-finger protein ZFP318 is essential for expression of IgD, the alternatively spliced Igh product made by mature $B$ lymphocytes. Proc Natl Acad Sci U S A. 2014;111(12):4513-8. Epub 2014/03/13. doi: 10.1073/pnas.1402739111. PubMed PMID: 24616512; PubMed Central PMCID: PMCPMC3970522. 100. van Dijk EL, Jaszczyszyn Y, Naquin D, Thermes C. The Third Revolution in Sequencing Technology. Trends Genet. 2018. Epub 2018/06/27. doi: 10.1016/j.tig.2018.05.008. PubMed PMID: 29941292.

101. Weirather JL, de Cesare M, Wang Y, Piazza P, Sebastiano V, Wang XJ, et al. Comprehensive comparison of Pacific Biosciences and Oxford Nanopore Technologies and their applications to transcriptome analysis. F1000Res. 2017;6:100. Epub 2017/09/07. doi: 10.12688/f1000research.10571.2. PubMed PMID: 28868132; PubMed Central PMCID: PMCPMC5553090.

102. Anvar SY, Allard G, Tseng E, Sheynkman GM, de Klerk E, Vermaat M, et al. Full-length mRNA sequencing uncovers a widespread coupling between transcription initiation and mRNA processing. Genome Biol. 2018;19(1):46. Epub 2018/03/31. doi: 10.1186/s13059-018-1418-0. PubMed PMID: 29598823; PubMed Central PMCID: PMCPMC5877393.

103. Oikonomopoulos S, Wang YC, Djambazian H, Badescu D, Ragoussis J. Benchmarking of the Oxford Nanopore MinION sequencing for quantitative and qualitative assessment of CDNA populations. Sci Rep. 2016;6:31602. Epub 2016/08/25. doi: 10.1038/srep31602. PubMed PMID: 27554526; PubMed Central PMCID: PMCPMC4995519 and the MinION instrument and R7, R7.3 flowcells were received free of charge.

104. Levy SE, Myers RM. Advancements in Next-Generation Sequencing. Annu Rev Genomics Hum Genet. 2016;17:95-115. Epub 2016/07/01. doi: 10.1146/annurev-genom-083115-022413. PubMed PMID: 27362342.

105. Garalde DR, Snell EA, Jachimowicz D, Sipos B, Lloyd JH, Bruce M, et al. Highly parallel direct RNA sequencing on an array of nanopores. Nat Methods. 2018;15(3):201-6. Epub 2018/01/16. doi: 10.1038/nmeth.4577. PubMed PMID: 29334379.

106. Bryant HE, Wadd SE, Lamond Al, Silverstein SJ, Clements JB. Herpes simplex virus IE63 (ICP27) protein interacts with spliceosome-associated protein 145 and inhibits splicing prior to the first catalytic step. J Virol. 2001;75(9):4376-85. Epub 2001/04/05. doi: 10.1128/JVI.75.9.4376-4385.2001. PubMed PMID: 11287586; PubMed Central PMCID: PMCPMC114182.

107. Hashizume $C$, Kuramitsu $M$, Zhang $X$, Kurosawa $T$, Kamata $M$, Aida Y. Human immunodeficiency virus type $1 \mathrm{Vpr}$ interacts with spliceosomal protein SAP145 to mediate cellular pre-mRNA splicing inhibition. Microbes Infect. 2007;9(4):490-7. Epub 2007/03/10. doi: 10.1016/j.micinf.2007.01.013. PubMed PMID: 17347016.

108. Verma D, Bais S, Gaillard M, Swaminathan S. Epstein-Barr Virus SM protein utilizes cellular splicing factor SRp20 to mediate alternative splicing. J Virol. 2010;84(22):11781-9. Epub 2010/09/03. doi: 10.1128/JVI.01359-10. PubMed PMID: 20810723; PubMed Central PMCID: PMCPMC2977868.

109. Klymenko T, Hernandez-Lopez H, MacDonald Al, Bodily JM, Graham SV. Human Papillomavirus E2 Regulates SRSF3 (SRp20) To Promote Capsid Protein Expression in Infected Differentiated Keratinocytes. J Virol. 2016;90(10):5047-58. Epub 2016/03/11. doi: 10.1128/JVI.0307315. PubMed PMID: 26962216; PubMed Central PMCID: PMCPMC4859725.

110. Qiu Y, Nemeroff M, Krug RM. The influenza virus NS1 protein binds to a specific region in human U6 snRNA and inhibits U6-U2 and U6-U4 snRNA interactions during splicing. RNA. 1995;1(3):304-16. Epub 1995/05/01. PubMed PMID: 7489502; PubMed Central PMCID: PMCPMC1369083. 
111. Fortes P, Lamond Al, Ortin J. Influenza virus NS1 protein alters the subnuclear localization of cellular splicing components. J Gen Virol. 1995;76 ( Pt 4):1001-7. Epub 1995/04/01. doi: 10.1099/0022-1317-76-4-1001. PubMed PMID: 9049349.

112. Mor A, White A, Zhang K, Thompson M, Esparza M, Munoz-Moreno R, et al. Influenza virus mRNA trafficking through host nuclear speckles. Nat Microbiol. 2016;1(7):16069. Epub 2016/08/31. doi: 10.1038/nmicrobiol.2016.69. PubMed PMID: 27572970; PubMed Central PMCID: PMCPMC4917225.

113. Thompson MG, Munoz-Moreno R, Bhat P, Roytenberg R, Lindberg J, Gazzara MR, et al. Coregulatory activity of hnRNP K and NS1-BP in influenza and human mRNA splicing. Nat Commun. 2018;9(1):2407. Epub 2018/06/21. doi: 10.1038/s41467-018-04779-4. PubMed PMID: 29921878; PubMed Central PMCID: PMCPMC6008300.

114. Fitzgerald KD, Chase AJ, Cathcart AL, Tran GP, Semler BL. Viral proteinase requirements for the nucleocytoplasmic relocalization of cellular splicing factor SRp20 during picornavirus infections. J Virol. 2013;87(5):2390-400. Epub 2012/12/21. doi: 10.1128/JVI.02396-12. PubMed PMID: 23255796; PubMed Central PMCID: PMCPMC3571363.

115. Alvarez E, Castello A, Carrasco L, Izquierdo JM. Poliovirus 2A protease triggers a selective nucleo-cytoplasmic redistribution of splicing factors to regulate alternative pre-mRNA splicing. PLoS One. 2013;8(9):e73723. Epub 2013/09/26. doi: 10.1371/journal.pone.0073723. PubMed PMID: 24066065; PubMed Central PMCID: PMCPMC3774746.

116. Liu YC, Kuo RL, Lin JY, Huang PN, Huang Y, Liu H, et al. Cytoplasmic viral RNA-dependent RNA polymerase disrupts the intracellular splicing machinery by entering the nucleus and interfering with Prp8. PLoS Pathog. 2014;10(6):e1004199. Epub 2014/06/27. doi: 10.1371/journal.ppat.1004199. PubMed PMID: 24968230; PubMed Central PMCID: PMCPMC4072778.

117. Lawrence $P$, Schafer EA, Rieder E. The nuclear protein Sam68 is cleaved by the FMDV $3 C$ protease redistributing Sam68 to the cytoplasm during FMDV infection of host cells. Virology. 2012;425(1):40-52. Epub 2012/01/28. doi: 10.1016/j.virol.2011.12.019. PubMed PMID: 22280896. 118. Dhillon P, Tandra VN, Chorghade SG, Namsa ND, Sahoo L, Rao CD. Cytoplasmic Relocalization and Colocalization with Viroplasms of Host Cell Proteins, and Their Role in Rotavirus Infection. J Virol. 2018;92(15). Epub 2018/05/18. doi: 10.1128/JVI.00612-18. PubMed PMID: 29769336; PubMed Central PMCID: PMCPMC6052293.

119. Burnham AJ, Gong L, Hardy RW. Heterogeneous nuclear ribonuclear protein K interacts with Sindbis virus nonstructural proteins and viral subgenomic mRNA. Virology. 2007;367(1):212-21. Epub 2007/06/15. doi: 10.1016/j.virol.2007.05.008. PubMed PMID: 17561226.

120. Dickson AM, Anderson JR, Barnhart MD, Sokoloski KJ, Oko L, Opyrchal M, et al. Dephosphorylation of HuR protein during alphavirus infection is associated with HuR relocalization to the cytoplasm. J Biol Chem. 2012;287(43):36229-38. Epub 2012/08/24. doi: 10.1074/jbc.M112.371203. PubMed PMID: 22915590; PubMed Central PMCID: PMCPMC3476290.

121. Shwetha S, Kumar A, Mullick R, Vasudevan D, Mukherjee N, Das S. HuR Displaces Polypyrimidine Tract Binding Protein To Facilitate La Binding to the 3' Untranslated Region and Enhances Hepatitis C Virus Replication. J Virol. 2015;89(22):11356-71. Epub 2015/09/05. doi: 10.1128/JVI.01714-15. PubMed PMID: 26339049; PubMed Central PMCID: PMCPMC4645635. 122. Redondo N, Madan V, Alvarez E, Carrasco L. Impact of Vesicular Stomatitis Virus M Proteins on Different Cellular Functions. PLoS One. 2015;10(6):e0131137. Epub 2015/06/20. doi: 10.1371/journal.pone.0131137. PubMed PMID: 26091335; PubMed Central PMCID: PMCPMC4474437.

123. Hegele A, Kamburov A, Grossmann A, Sourlis C, Wowro S, Weimann M, et al. Dynamic protein-protein interaction wiring of the human spliceosome. Mol Cell. 2012;45(4):567-80. Epub 2012/03/01. doi: 10.1016/j.molcel.2011.12.034. PubMed PMID: 22365833. 
902 124. Liu W, Lin YT, Yan XL, Ding YL, Wu YL, Chen WN, et al. Hepatitis B virus core protein inhibits

903 Fas-mediated apoptosis of hepatoma cells via regulation of $\mathrm{mFas} /$ FasL and sFas expression. FASEB J.

904 2015;29(3):1113-23. Epub 2014/12/04. doi: 10.1096/fj.14-263822. PubMed PMID: 25466893.

905 
A

\begin{tabular}{lcc}
\hline $\begin{array}{l}\text { Viral } \\
\text { family }\end{array}$ & $\begin{array}{c}\text { Viral } \\
\text { species }\end{array}$ & $\begin{array}{c}\text { Viral } \\
\text { proteins } \\
\text { (non-redundant) }\end{array}$ \\
\hline Papillomaviridae & $\mathbf{9}$ & $\mathbf{3 4 ( 3 4 )}$ \\
\hline Retroviridae & $\mathbf{8}$ & $\mathbf{1 7 ( 1 7 )}$ \\
\hline Herpesviridae & $\mathbf{5}$ & $\mathbf{4 9 ( 3 6 )}$ \\
\hline Flaviviridae & $\mathbf{4}$ & $\mathbf{9 ( 4 )}$ \\
\hline Togaviridae & 3 & $3(3)$ \\
\hline Paramyxoviridae & 2 & $4(3)$ \\
\hline Polyomaviridae & 2 & $3(3)$ \\
\hline Coronaviridae & 2 & $2(2)$ \\
\hline Parvoviridae & 2 & $2(2)$ \\
\hline Rhabdoviridae & 2 & $2(2)$ \\
\hline Orthomyxoviridae & $\mathbf{1}$ & $\mathbf{2 7}(11)$ \\
\hline Poxviridae & 1 & $13(12)$ \\
\hline Filoviridae & 1 & $2(2)$ \\
\hline Pneumoviridae & 1 & $2(2)$ \\
\hline Adenoviridae & 1 & $1(1)$ \\
\hline Circoviridae & 1 & $1(1)$ \\
\hline Hepadnaviridae & 1 & $1(1)$ \\
\hline Peribunyaviridae & 1 & $1(1)$ \\
\hline Phenuiviridae & 1 & $1(1)$ \\
\hline Reoviridae & 1 & $1(1)$ \\
\hline Total & 49 & $\mathbf{1 7 5 ( 1 3 9 )}$ \\
\hline
\end{tabular}

B

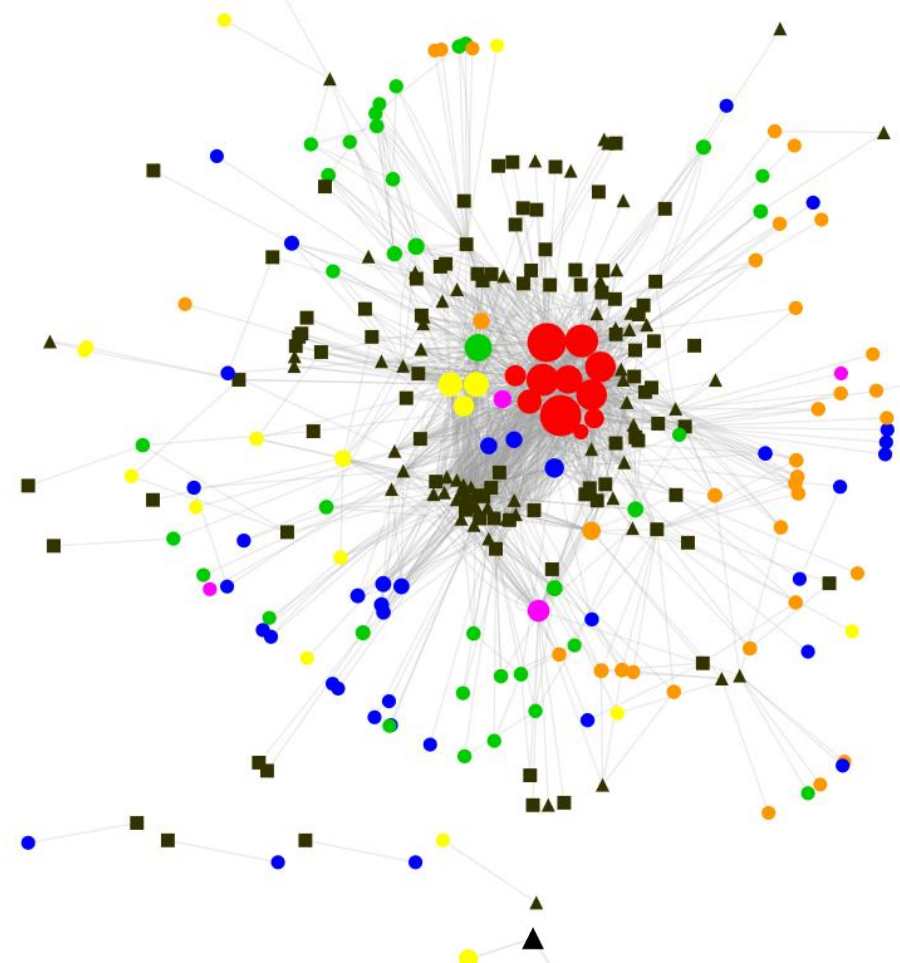

C

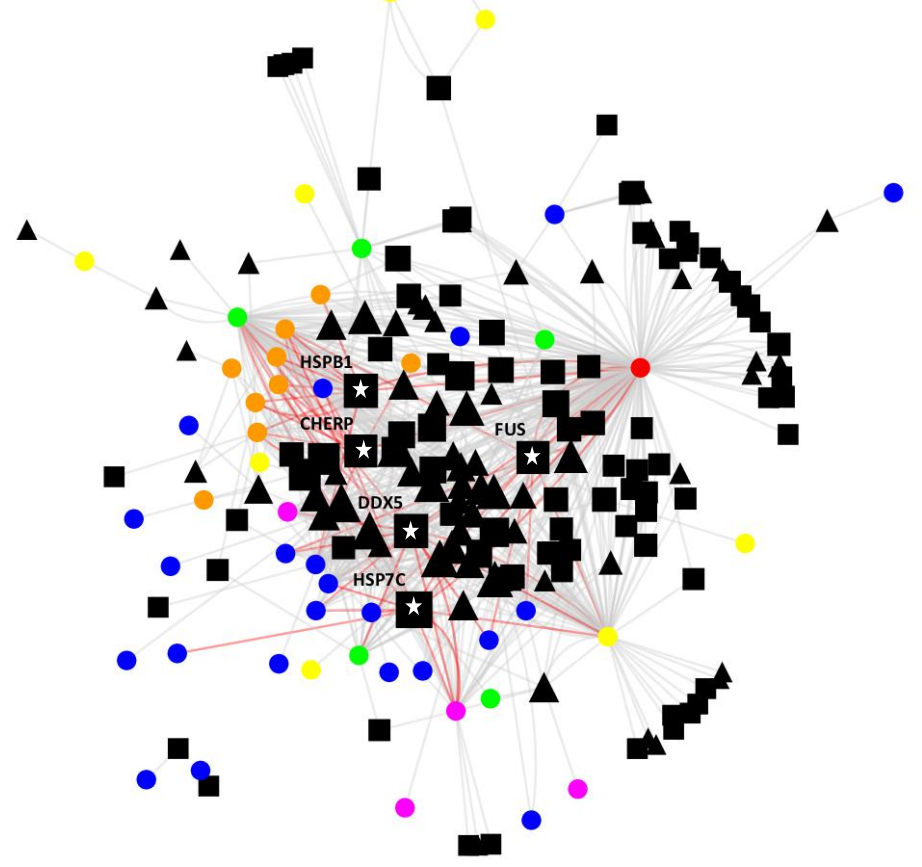


